\title{
PENGARUH MINAT MEMBACA DAN PENGUASAAN KOSAKATA TERHADAP KETERAMPILAN MENULIS NARASI SISWA KELAS V SDN SEKECAMATAN ALIAN TAHUN AJARAN 2019/2020
}

\author{
Alfiya Hikmawati, Rokhmaniyah, Ngatman \\ Universitas Sebelas Maret \\ alfiyahikmawati@student.uns.ac.id
}

\section{Article History \\ accepted 01/06/2020}

approved 01/07/2020 published 01/08/2020

\begin{abstract}
Reading interest and vocabulary mastery affect the language style in writing narrative texts. The study aimed to prove positive correlation of: reading interest on narrative writing skills, vocabulary mastery on narrative writing skills, reading interest and vocabulary mastery on narrative writing skills for fifth grade students of public elementary schools in Alian sub-district in academic year of 2019/2020. The research used quantitative research design with correlation method. Sampling method was cluster random sampling technique. SPSS version 18 was applied in analysing correlation data. The result indicated that the correlation coefficient between reading interest and vocabulary mastery on narrative writing skills was 0.169 with Sig. $F$ Change $=0,000<0.05$ and the value of adjusted $R$-squared variables was $5.1 \%$. It concludes that there are positive and significant effects between reading interest and vocabulary mastery on narrative writing skills to fifth grade students of public elementary schools in Alian subdistrict.
\end{abstract}

Keywords: interest, reading, vocabulary, narrative writing

\section{Abstrak}

Minat membaca dan penguasaan kosakata berpengaruh terhadap penguasaan unsur intrinsik untuk dapat menulis karangan narasi. Penelitian ini bertujuan untuk membuktikan (1) korelasi positif minat membaca terhadap keterampilan menulis narasi; (2) korelasi positif penguasaan kosakata terhadap keterampilan menulis narasi; (3) korelasi positif minat membaca dan penguasaan kosakata terhadap keterampilan menulis narasi siswa kelas V SDN se-Kecamatan Alian tahun ajaran 2019/2020. Penelitian ini merupakan penelitian kuantitatif dengan metode korelasi. Pengambilan sampel dilakukan dengan teknik cluster random sampling. Pada analisis data, peneliti menggunakan aplikasi SPSS versi 18 dalam menganalisis korelasi data. Hasil penelitian menunjukkan bahwa nilai koefisien korelasi antara minat membaca dan penguasaan kosakata terhadap keterampilan menulis narasi sebesar 0,169 dengan nilai Sig. F Change = $0,000<0,05$ dan nilai sumbangan efektif variabel sebesar $5,1 \%$. Berdasarkan analisis penelitian disimpulkan bahwa terdapat pengaruh yang positif dan signifikan antara minat membaca dan penguasaan kosakata terhadap keterampilan menulis narasi siswa kelas $V$ SDN se-Kecamatan Alian.

Kata kunci: minat, membaca, kosakata, menulis narasi 


\section{PENDAHULUAN}

Menulis merupakan keterampilan yang paling sulit diantara empat keterampilan berbahasa yang lain. Hal tersebut selaras dengan pendapat Nurgiyantoro (2016: 422) yang mengemukakan bahwa dibanding tiga kompetensi berbahasa yang lain, kompetensi menulis secara umum boleh dikatakan lebih sukar dikuasai bahkan oleh penutur asli bahasa yang berkaitan sekalipun.

Seseorang dalam menguasai keterampilan menulis dipengaruhi oleh beberapa faktor. Menurut Maryuningsih (2014: 3) faktor itu meliputi psikologi, intelektual, teknis, dan minat membaca penulis sedangkan faktor eksternal meliputi sarana dan prasarana yang mendukung aktivitas menulis. Menurut Dalman (2016: 106) menulis narasi merupakan kegiatan menulis cerita yang mengisahkan perilaku manusia dalam sebuah peristiwa dari waktu ke waktu yang disusun secara sistematis.

Minat membaca yaitu ketertarikan secara mendalam diiringi dengan perasaan bahagia terhadap aktivitas membaca sehingga dapat membimbing seseorang untuk membaca dengan kehendak pribadi. Faktor yang mempengaruhi minat membaca adalah faktor personal. Faktor personal yaitu faktor yang bersumber dari kepribadian anak itu sendiri meliputi usia, jenis kelamin, kemampuan membaca, intelegensi, kebutuhan psikologis, sikap (Cain, 2014: 672).

Faktor utama yang menyebabkan kurangnya minat membaca anak yaitu rasa bosan yang sering muncul. Ini lantaran anak itu lebih menyukai bermain dan juga kurang pengawasan dari orang tua. Hal tersebut menjadi kendala dalam meningkatkan minat membaca anak (Chatterji, $2016: 501$ ).

Kosakata memiliki posisi yang penting untuk landasan siswa dalam menguasai materi mata pelajaran bahasa Indonesia. Penguasaan kosakata dapat menentukan kecakapan siswa dalam berbahasa karena penguasaan kosakata memengaruhi kreativitas dan cara berpikir siswa dalam proses pembelajaran bahasa (Pramesti, 2015: 83).

Hal itu dapat dipahami karena kualitas dan kuantitas perbendaharaan kata atau kosakata yang dimiliki dapat menolong siswa dalam menerima berbagai informasi yang diberikan para pengajar atau sumber belajar lainnya. Penguasaan kosakata yang baik juga sangat memengaruhi kemampuan siswa dalam berkomunikasi, baik lisan dan tulisan. Dengan penguasaan kata yang baik, siswa lebih mudah mengungkapkan segala pikiran, gagasan, pendapat, dan perasaannya kepada orang lain (Ahmad, 2014: 3).

Pentingnya pembelajaran kosakata terhadap pengembangan dan peningkatan kemampuan berbahasa siswa menyebabkan pembelajaran kosakata semakin mendesak untuk dilakukan secara lebih terarah dan serius. Hal tersebut disebabkan oleh kenyataan di sekolah masih banyak ditemui siswa yang mengalami kesulitan dalam melaksanakan pembelajaran bahasa Indonesia. Kesulitan ini tampak pada pembelajaran empat keterampilan berbahasa yang disebabkan kemampuan penguasaan kosakata bahasa Indonesianya yang rendah (Anjarwati, 2016: 13).

Rendahnya tingkat menulis sebuah karangan narasi harus dapat diimbangi dengan cara menumbuhkan kemauan dan konsistensi. Namun berdasarkan temuan Naskah Akademik Kajian Kebijakan Kurikulum Mata Pelajaran Bahasa Indonesia (2007: 9) masih ditemukan permasalahan dalam pembelajaran bahasa Indonesia antara lain kesulitan dalam merumuskan kegiatan pembelajaran yang sesuai dengan kompetensi dasar serta kurangnya pemetaan kompetensi dasar dari empat aspek 
berbahasa (mendengarkan, berbicara, membaca, dan menulis). Hal itu menunjukkan bahwa tingkat kemampuan menulis di Indonesia masih rendah (Astuti, 2016: 5).

Hasil survey Badan Pusat Statistik (BPS) pada 2012 mengungkapkan bahwa masyarakat kita belum menjadikan kegiatan membaca sebagai sumber utama dalam mendapatkan suatu informasi. Orang lebih memilih menonton TV $(91,7 \%)$ atau mendengarkan radio (18,8\%), sedangkan membaca (17,6\%). Menurut penelitian sebuah lembaga dunia terhadap daya baca di 61 negara, Indonesia berada di peringkat ke 60 (Kompas, 7 Februari 2017). Jika minat membaca masyarakat Indonesia masih rendah, maka kosakata yang dikuasai juga masih rendah. Indikator rendahnya minat membaca ini dihitung dari jumlah buku yang diterbitkan memang masih jauh dari Singapura, Malaysia, India, dan negara maju lainnya (Muslim, Suyono \& Nuchasanah, 2017: 57).

Berdasarkan hasil wawancara dengan guru, minat membaca dan penguasaan kosakata siswa masih perlu ditingkatkan lagi. Hal tersebut dapat dilihat dari rendahnya minat membaca yang dimiliki siswa dan sedikitnya kosakata yang dikuasai siswa. Selain itu, keterampilan menulis narasi jarang dilaksanakan karena keterbatasan waktu pembelajaran. Hal tersebut mendorong penulis untuk melakukan penelitian dengan judul "Pengaruh Minat Membaca dan Penguasaan Kosakata Terhadap Keterampilan Menulis Narasi Kelas V SDN se-Kecamatan Alian Tahun Ajaran 2019/2020".

\section{METODE}

Desain penelitian yang digunakan yaitu penelitian kuantitatif dengan metode korelasi dengan analisis regresi. Menurut Rahmatina (2011: 73) regresi adalah analisis yang berguna untuk memeriksa atau memodelkan hubungan diantara variabelvariabel.Populasi penelitian ini yaitu siswa kelas V SDN se-Kecamatan Alian sejumlah 849 siswa dengan sampel sebanyak 294 siswa di sebelas SDN di Kecamatan Alian. Teknik sampling yang digunakan yaitu cluster random sampling.

Teknik pengumpulan data pada penelitian ini yaitu angket dan tes. Angket digunakan untuk pengumpulan data penelitian pada variabel minat membaca, sedangkan tes digunakan untuk mengumpulkan data pada variabel penguasaan kosakata dan keterampilan menulis narasi. Pada penelitian ini, untuk menghitung reliabilitas peneliti menggunakan rumus Cronbach's Alpha.

Peneliti menggunakan aplikasi SPSS versi 18 dalam menguji hipotesis. Uji prasyarat data penelitian ini yaitu uji normalitas data, uji linieritas data, dan uji multikolinieritas data. Setelah data memenuhi prasyarat yang ditentukan, data akan dianalisis menggunkan analisis regresi berganda, analisis korelasi berganda, dan sumbangan efektif.

\section{HASIL DAN PEMBAHASAN}

Penelitian dilakukan dengan memberikan angket minat membaca serta soal tes penguasaan kosakata dan keterampilan menulis narasi di SD yang menjadi sampel penelitian. Uji prasyarat data pada penelitian ini telah terpenuhi yaitu data berdistribusi normal dan data berhubungan linier. 
Tabel 1. Hasil Analisis Uji Normalitas Variabel Minat Membaca

Tests of Normality

\begin{tabular}{cccc}
\hline & \multicolumn{3}{c}{ Kolmogorov-Smirnov } \\
\cline { 2 - 4 } & Statistic & df & Sig. \\
\hline Minat Membaca &, 052 & 279 &, 064 \\
\hline
\end{tabular}

Tabel 2. Hasil Analisis Uji Normalitas Variabel Penguasaan Kosakata

Tests of Normality

\begin{tabular}{lccc}
\hline & \multicolumn{3}{c}{ Kolmogorov-Smirnov } \\
\cline { 2 - 4 } & Statistic & df & Sig. \\
\hline Penguasaan Kosakata &, 053 & 279 &, 054 \\
\hline
\end{tabular}

Tabel 3. Hasil Analisis Uji Normalitas Variabel Keterampilan Menulis Narasi

Tests of Normality

\begin{tabular}{lccc}
\hline & \multicolumn{3}{c}{ Kolmogorov-Smirnov } \\
\cline { 2 - 4 } & Statistic & df & Sig. \\
\hline Keterampilan Menulis Narasi &, 053 & 279 &, 057 \\
\hline
\end{tabular}

Data minat membaca berdistribusi normal ditunjukkan dengan nilai signifikasi sebesar 0,064 pada tabel 1 , data penguasaan kosakata berdistribusi normal dengan nilai signifikansi sebesar 0,054 pada tabel 2 , dan data keterampilan menulis narasi berdistribusi normal dengan nilai signifikansi sebesar 0,057 pada tabel 3 . Nilai signifikansi tersebut menunjukkan $>0,05$ sehingga data berdistribusi normal.

Tabel 4. Hasil Uji Linieritas Data Minat Membaca terhadap Keterampilan Menulis Narasi

\begin{tabular}{llll}
\hline & & $F$ & Sig. \\
\hline Keterampilan & (Combined) &, 996 &, 560 \\
Menulis Narasi & Linearity & 6,232 &, 015 \\
Siswa Kelas V * & Deviation from &, 952 &, 613 \\
Minat Membaca & Linearity & & \\
\hline
\end{tabular}

Tabel 5. Hasil Uji Linieritas Data Penguasaan Kosakata terhadap Keterampilan Menulis Narasi

\begin{tabular}{llll}
\hline & & F & Sig. \\
\hline Keterampilan Menulis & (Combined) & 1,675 &, 030 \\
Narasi Siswa Kelas V * & Linearity & 10,374 &, 001 \\
Penguasaan Kosakata & Deviation from & 1,280 &, 185 \\
& Linearity & & \\
\hline
\end{tabular}

Data minat membaca dengan data keterampilan menulis narasi memiliki hubungan yang linier ditunjukkan dari nilai Sig. Deviation from Linearity sebesar 0,613 pada tabel 4 dan data penguasaan kosakata dengan data keterampilan menulis narasi 
memiliki hubungan yang linier ditunjukkan dari nilai Sig. Deviation from Linearity sebesar 0,185 pada tabel 5 . Nilai Sig. Deviation from Linearity $>0,05$ sehingga data tersebut memiliki hubungan yang linier.

Tabel 6 Hasil Uji Multikolinieritas

Coefficients $^{\mathrm{a}}$

\begin{tabular}{lcc}
\hline \multirow{2}{*}{ Model } & \multicolumn{2}{c}{ Collinearity Statistics } \\
\cline { 2 - 3 } & Tolerance & VIF \\
\hline (Constant) & & \\
Minat Membaca & .976 & 1.024 \\
Penguasaan Kosakata & .976 & 1.024 \\
\hline
\end{tabular}

a. Dependent Variable: Keterampilan Menulis Narasi Siswa Kelas V

Berdasarkan tabel hasil uji multikolinieritas diketahui nilai tolerance yaitu 0,976 dan nilai VIF yaitu 1,024. Hal itu berarti nilai tolerance $>0,10$ dan nilai VIF $<10,0$ maka Ho diterima. Jadi dapat disimpulkan bahwa tidak terjadi multikolinieritas antarvariabel bebas pada penelitian ini dan analisis regresi ganda dapat dilanjutkan.

Tabel 7. Hasil Analisis Korelasi Sikap Sosial dan Hasil Belajar IPS

\begin{tabular}{|c|c|c|c|c|}
\hline \multicolumn{5}{|c|}{ Correlations } \\
\hline \multicolumn{2}{|c|}{ Control Variables } & \multirow{2}{*}{$\begin{array}{c}\begin{array}{c}\text { Minat } \\
\text { Membaca }\end{array} \\
1.000\end{array}$} & \multirow{2}{*}{$\begin{array}{l}\begin{array}{l}\text { Penguasaan } \\
\text { Kosakata }\end{array} \\
.154\end{array}$} & \multirow{2}{*}{$\begin{array}{l}\text { Keterampilan Menulis } \\
\text { Narasi Siswa Kelas V } \\
.151\end{array}$} \\
\hline & Correlation & & & \\
\hline Minat & Significance & . & .010 & .012 \\
\hline \multirow[t]{3}{*}{ Membaca } & (2-tailed) & & & \\
\hline & $d f$ & 0 & 277 & 277 \\
\hline & Correlation & .154 & 1.000 & .188 \\
\hline \multirow{3}{*}{$\begin{array}{l}\text { Penguasaan } \\
\text { Kosakata }\end{array}$} & Significance & .010 & . & .002 \\
\hline & (2-tailed) & & & \\
\hline & $d f$ & 277 & 0 & 277 \\
\hline Keterampilan & Correlation & .151 & .188 & 1.000 \\
\hline Menulis & Significance & .012 & .002 & \\
\hline Narasi Siswa & (2-tailed) & & & \\
\hline Kelas V & df & 277 & 277 & 0 \\
\hline
\end{tabular}

a. Cells contain zero-order (Pearson) correlations.

Berdasarkan analisis yang telah dilakukan, diketahui nilai Sig. (2-tailed) $\mathrm{H}_{1}, \mathrm{H}_{2}$, dan $\mathrm{H}_{3}$ yaitu 0,$151 ; 0,188 ; 0,169$ pada tabel 7 . Hal ini berarti nilai signifikansi $<\alpha(0,000$ $<0,05)$, artinya hipotesis penelitian ini dapat diterima atau terdapat hubungan positif 
antara minat membaca dan penguasaan kosakata terhadap keteramilan menulis narasi siswa kelas V SDN se-Kecamatan Alian tahun ajaran 2019/2020. Hasil penelitian ini sesuai dengan penelitian yang dilakukan oleh Fitriani (2018) dengan judul "Pengaruh Minat Membaca dan Penguasaan Kosakata terhadap Kemampuan Menulis Cerpen" menghasilkan bahwa ada pengaruh antara minat membaca dengan kemampuan menulis cerpen. Oleh karena itu, dapat dikatakan bahwa semakin tinggi minat membaca dan penguasaan kosakata, maka akan semakin tinggi pula keterampilan menulis narasi siswa, begitu pun sebaliknya.

Hasil perhitungan sumbangan efektif pada variabel minat membaca terhadap keterampilan menulis narasi sebesar $1,9 \%$, artinya minat membaca berperan dalam meningkatkan keterampilan menulis narasi sebesar $1,9 \%$ dan sisanya sebesar $98,1 \%$ dipengaruhi oleh faktor lain misalnya cita-cita, intelegensi, dan sebagainya. Sumbangan efektif pada variabel penguasaan kosakata terhadap keterampilan menulis narasi sebesar $3,2 \%$, artinya penguasaan kosakata berperan dalam meningkatkan keterampilan menulis narasi sebesar 3,2\% dan sisanya sebesar 96,8\% dipengaruhi oleh faktor lain misalnya banyaknya kata yang dikuasai dan penguasaan gramatika. Sumbangan efektif pada variabel minat membaca dan penguasaan kosakata terhadap keterampilan menulis narasi sebesar $5,1 \%$, artinya minat membaca dan penguasaan kosakata berperan dalam meningkatkan keterampilan menulis narasi sebesar $5,1 \%$ dan sisanya sebesar $94,9 \%$ dipengaruhi oleh faktor lain.

\section{SIMPULAN}

Berdasarkan hasil penelitian dapat ditarik kesimpulan sebagai berikut:

1. Minat membaca berkorelasi positif terhadap keterampilan menulis narasi siswa kelas V SDN se-Kecamatan Alian tahun ajaran 2019/2020 dengan tingkat korelasi lemah yaitu 0,151 . Besarnya sumbangan efektif variabel minat membaca terhadap keterampilan menulis narasi sebesar $1,9 \%$.

2. Penguasaan kosakata berkorelasi positif terhadap keterampilan menulis narasi siswa kelas V SDN se-Kecamatan Alian tahun ajaran 2019/2020 dengan tingkat korelasi lemah yaitu 0,188 . Besarnya sumbangan efektif variabel penguasaan kosakata terhadap keterampilan menulis narasi sebesar 3,2\%.

3. Minat membaca dan penguasaan kosakata berkorelasi positif terhadap keterampilan menulis narasi siswa kelas V SDN se-Kecamatan Alian tahun ajaran $2019 / 2020$ dengan tingkat korelasi lemah yaitu 0,169. Sumbangan efektif variabel minat membaca dan penguasaan kosakata secara bersama-sama terhadap keterampilan menulis narasi sebesar $5,1 \%$.

Peneliti mengajukan saran sebagai berikut: (1) guru dapat memerhatikan siswa agar lebih giat untuk membaca sehingga dapat meningkatkan keterampilan menulis narasi, (2) sekolah diharapkan memberikan dukungan kepada guru untuk meningkatkan pembelajaran, dan (3) peneliti selanjutnya diharapkan dapat mengembangkan penelitian dengan membahas faktor lain yang memengaruhi keterampilan menulis narasi. 


\section{DAFTAR PUSTAKA}

Ahmad, C. N. (2014). Pengaruh Minat Baca dan Penguasaan Kosakata terhadap Keterampilan Menulis Bahasa Jerman Peserta Didik Kelas XI SMA Negeri 2 Wonogiri. Skripsi Tidak Dipublikasikan, Universitas Negeri Yogyakarta, Yogyakarta.

Anjarwati, E. (2016). Pengaruh Penguasaan Kosakata terhadap Kemampuan Membaca Pemahaman Siswa SD Gugus Dewi Kunthi Kota Semarang. Skripsi Tidak Dipublikasikan, Universitas Negeri Semarang, Semarang.

Astuti, L. D. (2016). Hubungan Penguasaan Kosakata dengan Kemampuan Menulis Karangan Narasi pada Siswa Kelas IV SDN Gugus Sultan Agung Kecamatan Pucakwangi Kabupaten Pati. Skripsi Tidak Dipublikasikan, Universitas Negeri Semarang, Semarang.

Cain, K., Oakhill, J., \& Lemmon, K. (2014). Individual differences in the inference of word meanings from context: The influence of reading comprehension, vocabulary knowledge, and memory capacity. Journal of Educational Psychology, 96(4), 671- 681.

Chatterji, M. (2016). Reading achievement gaps, correlates, and moderators of early reading achivement: Evidence from the early childhood longitudinal study (ECLS) kindergarten to first grade sample. Journal of Educational Psychology, 98(3), 489 $-507$.

Dalman. (2016). Keterampilan Menulis. Jakarta: PT Rajagrafindo Persada.

Maryuningsih. (2014). Hubungan Minat Membaca dengan Keterampilan Menulis Narasi Siswa Kelas IV Sekolah Dasar Se-Gugus Kecamatan Kraton Yogyakarta Tahun Ajaran 2013/2014. Skripsi Tidak Dipublikasikan, Universitas Negeri Yogyakarta, Yogyakarta.

Muslim, Suyono \& Nuchasanah. (2017). Pengaruh Minat Baca terhadap Prestasi Belajar Siswa Sekolah Dasar. Prosiding Seminar Nasional Teknologi Pembelajaran dan Pendidikan Dasar, hlm. 56-63. Malang: Universitas Negeri Malang.

Nurgiyantoro, B. (2016). Penilaian Pembelajaran Berbahasa Berbasis Kompetensi. Yogyakarta: BPFE-Yogyakarta.

Pramesti, U. D. (2015). Peningkatan Penguasaan Kosakata Bahasa Indonesia dalam Keterampilan Membaca melalui Teka-Teki (Penelitian Tindakan di Kelas VI SDN Surakarta 2, Kecamatan Suranenggala, Kabupaten Cirebon, Jawa Barat). Jurnal Puitika, 11(1), 82-93. Diperoleh pada 16 September 2019, dari jurnalpuitika.fib.unand.ac.id/index.php/jurnalpuitika/ article/view/17

Rahmatina, D. (2011). Analisis Regresi Linear pada Statistika Non Parametik. Laporan Penelitian Tidak Dipublikasikan. Universitas Maritim Raja Ali Haji Tanjungpinang. 